2. Sigitov, S. (1982). Gabriel Faure: a monograph. M.: Soviet composer 280 p. [in Russian].

3. Champagne, M. J. S. G. (1994). The French song cycle (1840-1924): with special emphasis on the works of Gabriel Fauré. University of North Carolina at Chapel Hill [in English].

4. Faure M., Vivès, V (2000). Histoire et poétique de la mélodie française. Paris : CNRS Editions [in French].

5. Gartside, R (1996). «Poème d'un jour» In Interpreting the Songs of Gabriel Fauré, Geneseo. NY: Leyerle Publications, p. 86-94 [in English].

6. Graham J. Stokes R. (2009) «Grandmougin and Poème D'un Jour». In Gabriel Fauré: The Songs and Their Poets, Farnham, England: Ashgate, 2009. 117-121 [in English].

7. Guide de la mélodie et du lied (1994). Sous la direction de B. Francois-Sappey et Gilles Cantagrel. Paris: Librairie Arthème Fayard [in French].

8. Histoire de la musique (1995). La musique occidentale du Moyen Age a nos jours. sous la direction de Marie-Claire Beltrando-Partier. Paris : Bordas [in French].

9. Jankelevitch, V (1974). Faure et I' inexprimable. Paris [in French].

10. Kimball, C. (2006). Gabriél Fauré. In Song: A Guide to Art Song Style and Literature. Milwaukee, WI: Hal Leonard, 2006 [in English].

11. Nectoux, J. (1972) M. Fauré. Paris : Seuil [in French].

12. Verlaine, P. (1969) Euvres poétiques. Texte établi, avec chronologie, introduction, notes, choix de variantes et bibliographie par J. Robichez. P., Garnier [in French].

13. URL: http://scholarworks.bgsu.edu/cgi/viewcontent.cgi?article=1197\&context $=$ honorsprojects

Стаття надійшла до редакції 15.03.2017

УДК $78.03+782.1$

\author{
Лариса Миколаївна Лобода \\ кандидат мистецтвознавства, доцент кафедри \\ сольного співу Одеської національної \\ музичної академії імені А. В. Нежданової \\ loboda_l@i.ua
}

\title{
ОСОБЛИВОСТІ ВОКАЛЬНО-СЦЕНІЧНОГО ВТІЛЕННЯ ПЕРСОНАЖІВ ОПЕРНОГО ТВОРУ
}

Метою статті є виявлення театрально-сценічних принципів $і$ вокально-виконавських прийомів, що сприяють втіленню образних характеристик оперного персонажа. Методологічна основа статті полягає в історико-стильовому з особливою увагою до естетичного походження

С Лобода Л. М., 2017 
опери та смисловому призначенню музики, музикознавчому аналітичному, театрознавчому й стильовому підходах. Наукова новизна полягає в розгляді важливих вокально-виконавських, драматургічних і театрально-сценічних аспектів втілення персонажа оперного твору. Висновки. Таким чином, при роботі вокаліста над створенням образу оперного персонажа слід враховувати, що дія трактується як сукупність реакцій людини на обставини, вона входить до складу вчинку і підпорядковується його спонукальним мотивам та прагне до досягнення мети. Але дії та рух заздалегідь зазвичай не плануються лише у повсякденній реальності; сценічне життя, навпаки, передбачає наявність у виконавия обдуманих реакцій - навмисно видимі рухи і дї, що здійснюються від імені персонажа з єдиною метою - розкрити свідомі, несвідомі або приховані рухи думки, переживання героя. Отже лише у стані перевтілення співака в співака-актора, розпоряджаючись його психофізикою, сам персонаж виявляє дієву свободу.

Ключові слова: опера, оперний персонаж, сценічний образ, театрально-сценічні засоби виразності.

Loboda Larisa Nikolaevna, ph.d. in musical art, associate Professor of Solo Singing department theory of music and composition of the Odessa national A. V. Nezhdanova academy of music

Features of the vocal-scenic embodiment of the characters of the opera

The purpose of the article is to reveal theatrical-scenic principles and vocal-performing techniques that contribute to the embodiment of figurative characteristics of an opera character. The methodological basis of the article is historical and style, with special attention to the aesthetic origin of the opera and the semantic purpose of music, musicological analytical, theatrical and style approaches. The scientific novelty lies in the consideration of important vocal-performing, dramatic and theatrical scenic aspects of the embodiment of the character of the opera. Conclusions. Thus, when a vocalist works on creating an image of an opera character, one should take into account that the action is treated as a set of human reactions to circumstances, it is part of the action and is subordinated to its motive and purpose. But actions and movements in advance are usually not planned only in the ordinary reality; the stage life, on the contrary, presupposes in the performer deliberate reactions-deliberately visible movements and actions performed on behalf of the character with the sole purpose of revealing the conscious, unconscious or concealed motion of thought, the experience of the hero, that is, the invisible action. Consequently, only in the state of reincarnation of the singer-actor, managing his psychophysics, the character himself manifests an effective freedom.

Keywords: opera, opera character, stage image, theatrical scenic means of expressiveness. 
Лобода Лариса Николаевна, кандидат искусствоведения, доцент кафедры сольного пения Одесской национальной музыкальной академии имени А. В. Неждановой

Особенности вокально-сценического воплощения персонажей оперного произведения

Цель статьи - выявление театрально-сценических приниипов и вокально-исполнительских приемов, способствующих воплощению образных характеристик оперного персонажа. Методологическая основа статьи заключается в историко-стилевом с особым вниманием $к$ эстетическому происхождению оперы и смысловому назначению музыки, музыковедческом аналитическом, театроведческом и стилевом подходах. Научная новизна заключается в рассмотрении важных вокально-исполнительских, драматургических и театрально-сиенических аспектов воплощения персонажа оперного произведения. Выводы. Таким образом, при работе вокалиста над созданием образа оперного персонажа следует учитывать, что действие трактуется как совокупность реакций человека на обстоятельства, оно входит в состав поступка и подчинено его мотиву и цели. Но действия и движения заранее обычно не планируются лишь в обыденной реальности; сценическая жизнь, напротив, предполагает в исполнителе обдуманные реакции - намеренно видимые движения и действия, осуществляемые от лица персонажа с единственной иелью - раскрыть сознательное ли, бессознательное или утаиваемое движение мысли, переживание героя, то есть действие невидимое. Следовательно, лишь в состоянии перевоплощения певиа-актера, распоряжаясь его психофизикой, сам персонаж проявляет действенную свободу.

Ключевые слова: опера, оперный персонаж, сценический образ, театрально-сценические средства выразительности.

Актуальність даного дослідження підкреслюється тим, що практично у всіх дослідженнях, присвячених вивченню опери, важливим чинником називають синтетичність ii жанрової природи, яка хоча спочатку і була призначена для реалізації театральними і сценічними засобами, але в процесі еволюції саме особливий тип музично інтонуємого слова протягом тривалого часу займав провідне місце. Разом з тим сучасні соціокультурні умови диктують нові правила і нові вимоги як до режисерів оперних вистав, так і до сучасних оперних виконавців. Інакше кажучи, не дивлячись на найпомітніші структурно-композиційні, стильові метаморфози й домінування музичного начала як провідного художнього призначення опери, iii нинішнє існування без опори на театрально-сценічний досвід майже неможливо. Також важливою теоретичною передумовою дослі- 
дження стає розгляд природи опери у цілому, виявлення жанрових витоків опери як естетичного феномена, який формує і висловлює усуспільнені культурні смисли.

Метою статті $є$ виявлення театрально-сценічних принципів та вокально-виконавських прийомів, що сприяють втіленню образних характеристик оперного персонажа. Методологічна основа статті полягає в історико-стильовому з особливою увагою до естетичного походження опери та смисловому призначенню музики, музикознавчому аналітичному, театрознавчому і стильовому підходах. Наукова новизна полягає в розгляді важливих вокально-виконавських, драматургічних і театрально-сценічних аспектів втілення персонажа оперного твору.

Огляд літератури з проблеми. Більшість досліджень, спрямованих на розкриття актуальних проблем сучасного оперознавства, відображають «музикоцентристську» дослідницьку позицію, на що вказує М. Черкашина-Губаренко. Розгляду у даному аспекті й визнанню домінуючого положення музичного рівня в опері як синтетичного жанру сприяє зосередження музикознавчої уваги на музичній партитурі. Грунтуючись на музикознавчому аналізі взаємозумовленості елементів музичної мови, можемо всебічно вивчити музичні закономірності, виявити їх зв'язки з культурно-історичним контекстом, виявити новаторські риси, а також наблизитися до осмислення і вивчення семантики оперного твору, що в свою чергу дозволить найбільш повно і точно відтворювати в процесі розгортання оперного твору його сценічні образи і персонажі.

При вивченні оперної спадщини як цілісного феномена актуальними виявляються дослідні ракурси, що зачіпають діалогічний, виконавський, комунікативний, креативний i, звичайно, семантичний аспекти творчості. Про більш широке трактування тексту опери пише М. Р. Черкашина-Губаренко в статті «Роздуми про феномен опери» [5], де підкреслює процес певного відокремлення музичної мови, як незалежного життя музичного шару в опері 3 посиленням уваги до сценографії опери, до його видовищного боку у постановках сучасних режисерів. «У поліфонічній партитурі оперного твору свій тематичний образ й звукове втілення знаходять місце існування та предмети, які беруть участь в інтризі. Навіть рельєфні теми-лейтмотиви, що характеризують символічні та алегоричні поняття (рок, заборона, чарівні чари, смерть), мають потенційні можливості бути представленими у конкретному сценічному образі, чим успішно користуються 
сучасні оперні режисери» $[5,47]$. Таким чином, автор вказує на посилення зустрічного руху між оперою і театром в сучасних режисерських інтерпретаціях оперних творів.

Виклад основного матеріалу. Важливе виконавське завдання створення музичного характеру є актуальним не тільки для вітчизняної, а й для світової оперної культури. Відомий австрійський і німецький театральний режисер і засновник театру «Komische Oper» Вальтер Фельзенштейн вказував, що спостерігав певні невтішні тенденції: «іноді й в дуже красивих, естетично і навіть музично здійснених постановках завжди страждав від того, що музика і спів в театральному сенсі ніколи не приймалися цілком серйозно, а співу бракувало правдивості й достовірності висловлювання з точки зору зображення людських характерів» [4, 23].

Як відомо, при підготовці сценічної постановки «Евгенія Онєгіна» П. Чайковського К. С. Станіславський з особливою ретельністю працював над втіленням музичного характеру, він усвідомлював, що закладає традицію складної драматургії оперного образу на основі наступності кращих традицій реалістичного психологічного театру, кращих досягнень оперного театру, видатного досвіду співаків-акторів (наприклад, Ф. Шаляпіна). К. Станіславський вказував, що «якщо кожен образ - це характер, знайдений нами в період репетиції, то ви завжди в нього перевтілитися, відтворивши думки і дії, які пов'язані тільки з цим характером» $[1,254]$.

У зв'язку з цим кожен сценічний персонаж слід визначати і трактувати як новий живий характер. Створення персонажного характеру $є$ провідною приналежністю нової особистості та має на увазі реструктуризацію психічного простору актора з метою створення нового оригінального змісту, який, в свою чергу, породжував би у виконавця виразову новизну рис та індивідуальних складових персонажа. Тому перед виконавцем стоїть складне творче завдання, пов'язане 3 необхідністю сценічного перевтілення, зміною логіки мислення, сприйняття, ритму реакцій на обставини сценічного життя, рівня емоційності та способів самовираження.

Оскільки оперний характер є за своєю природою сценічним феноменом, виявляє також його реалістичні властивості, бо в характері персонажа, за задумом драматурга, глядачеві дано пізнати себе. Драматург, композитор, як правило, показують сценічно дієвий, динамічний характер у поєднанні типового й індивідуального; зміни, які в ньому відбуваються, залежать від цілого ряду обставин, які виконав- 
цю належить виявити й проаналізувати в процесі роботи з текстом. В характері найбільш суттєвими є зміни, що відзначаються у тому випадку, коли відносини суперечливі і несприятливі. Це положення відсилає виконавця до значущості конфлікту й сили дії гранічної ситуації, а також трагічного модусу в творі. Перебуваючи в безперервному розвитку, характери визначаються та стабілізуються, тільки коли персонаж потрапляє в граничну ситуацію й виходить зміненим - переможцем або переможеним.

На відміну від драми характер оперного героя виникає з музичного середовища, хоча зазнає значного впливу з боку його драматургічної основи. Музика багато говорить про характер персонажа, якщо в драмі характер розкривається за принципом самовиявлення, самовираження, тобто через дію, мову (монолог і діалог), то в опері розкриттю характеру персонажа сприяють також метро-темпоритмічні, мелодико-гармонійні, музично-жанрові спрямування та темброві, звуковисотні, інструментальні, інтонаційні засоби. При роботі виконавця-вокаліста над створенням сценічного образу і втіленням характеру оперного персонажа співак-актор має звернути увагу на такі джерела інформації як музичний зміст образу, авторські ремарки - сценічні вказівки на психологічний або фізичний стан героя, відомості в лібрето і літературних першоджерелах, на мову персонажа й побічно на коментарі інших персонажів; в самохарактеристиці красномовними є також тембр, дикція, сценічна гра й такі спеціальні елементи як міміка, пластика, динамічні відтінки, метр, темп, ритмічний малюнок; лад, тональний план, гармонія; оркестровка; мелодійний малюнок, фразування, штрихи, паузи в інструментальній й вокальній партіях.

В оперному творі провідним началом, яке ініціює й безпосередньо слухову образність, в силу чого багато авторів вважають головним предметом музичного пізнання «емоційну сторону життя людського духу» і називають музику «стенографією почуттів», в тому числі маючи на увазі, що власна сфера музики може тлумачитися як ставлення людини до людини (до іншої людини і до самого себе), але відмовляючи їй в логіко-дискурсивній самостійності. Між іншим, висловити ставлення людини і до людини неможливо без останніх; але в музиці вони набувають свого специфічного характеру. Крім того, емоційну сторону життя відтворюють й інші, крім музики, види мистецтва, але, як уже було показано, кожен з видів мистецтв вирішує цю проблему по-своєму. Критерієм відмінностей між видами мистецтва повинні 
служити принципи їх системної упорядкованості у вигляді загальної моделі катартичих умов художнього впливу.

Музика дійсно являє найбільш «чисту» послідовність диалогічних зусиль мистецтва, тому що веде від безпосередньо оціночного сприйняття через розпізнавання мовних «норм» до охоплення композиційного цілого в його результуючих розділах. На відміну від літературної «логіки композиції» суттєві спрямування для змістовної сторони твору ми знаходимо, по-перше, в принциповій неможливості в процесі послідовного «живого» сприйняття «повернутися» («перечитати») до матеріалу, що вже прозвучав, що пояснює особливу необхідність повторень в музиці і їх особливі композиційні функції, особливе призначення музичної жанрової та стильової пам'яті, нарешті іншу, в порівнянні з літературною, природу музичного тексту як загального «матеріалу» музики; по-друге, в не тільки часовому, але і в просторовому характері музичної композиції.

Останній виражається безпосередньо в резонансних фізичних звукових явищах, в акустичних і виконавських умовах жанрів, опосередковано - в фактурних прийомах, що розвиваються через освоєння «горизонталі» і «вертикалі» музичного висловлювання до відкриття його «глибини» і навіть «діагоналі» (Н. Горюхіна, М. Ковалінас) [3].

Композиція в музиці як часове та тимчасове відповідає загальній жанрово-стильовій логіці у безпосередньо даних образних значеннях. Така відповідність обумовлює семантичні функції композиційних структур, дозволяє їм виступати досить прямими провідниками сенсу, символічно визначатися й отримувати автономну значимість. Втім в кожній окремій композиції така значимість переглядається заново. Точність цієї відповідності при ії підпорядкованості високим смислам сприяла виникненню уявлень про музичну форму як свідоцтва про присутність духу, безпосередньо духовну.

Вимогам такого аналізу художнього твору, який призведе до «психологічному синтезу», тобто відкриє шлях до цілісного розуміння художнього змісту (який виникає 3 протидій «матеріалу» і «форми» мистецтва), відповідає семантичний аналіз. Як підтверджує дослідження О. Самойленко, семантичний аналіз музики не досягає своєї повноти поза її семантичною типологією, таким чином, вимагаючи останньої. Семантична типологія в своїх найбільш загальних підставах виявляє ноетічну природу провідної музичної символіки і визначається ії диалогічними властивостями, отже може бути здійснена як типологія діалогу [3]. 
Характеризуючи принципи функціонування оперних творів, можна виявити, що хоча багато в чому вони схожі з театральними, самобутність їх полягає в тому, що провідне положення в опері займають сфери музичного мислення й музичної комунікації. Особливий інтерес для виконавця, має звернення до його здатності створювати та динамічно розвивати музичні портрети, в яких характер персонажа представлений опосередковано. Таке непряме портретування можна спостерігати у зв'язку з образом Людмили («Руслан і Людмила») в іiі каватині, що представляє один з іiі власних музичних портретів: в зверненнях до женихів є не тільки емоційно забарвлене ставлення - легка усмішка на адресу Фарлафа, а й мелодико-гармонійна характеристика об'єкта уваги, наприклад, виражений східний колорит гнучкої, томної синкопованої мелодії і ритму, елементи гармонічного мажору у зверненні до Ратміра.

Перехід від особливостей створення музичного характеру до дослідження тих елементів виразності в музиці, які повідомляють слухачеві про важливі риси оперного героя - надають персонажу характерність, а виконавцю в кожній оперній ролі необхідно вловити цю унікальну ознаку його героя. Дієва природа театрального актора $\epsilon$ провідною ознакою, що дозволяє відокремлювати театр від інших жанрів. Саме це мав на увазі великий трагічний актор М. Дальський, навчаючи свого юного учня Ф. Шаляпіна надавати оперним ролям театральність, вивільняти їх яскраве ігрове підгрунтя, яке виражається не тільки зовнішньо, але й у внутрішній дії.

Цей принцип отримав значний розвиток в театральній драматичній школі К. Станіславського. Режисер стверджував, що будь-яка жива істота діє («орієнтується»), виходячи зі своїх зв’язків і відносин з навколишнім середовищем, і що на підгрунті цього органічного закону природи необхідно будувати й сценічне дійство. Органічні дії актора на сцені необхідні і для глибокого розкриття і виявлення характеру діючої особи. У книзі про свого вчителя М. Горчаков зафіксував, що Станіславський шукав дії, що розкривають типові риси характеру, світогляд, ідеї, почуття, думки героя. Всі дії актора за роллю служать виявленню надзвичайного завдання; вони повинні бути цілеспрямовані і відібрані для розкриття характеру дійової особи у русі, у розвитку, та в них не повинно бути нічого випадкового й зайвого [1, 22].

В роботі вокаліста над оперним персонажем К. Станіславський мав на увазі під органічною дією цілісний комплекс психофізіологічних і емоційно-чуттєвих установок. Його послідовник В. Фельзен- 
штейн вважав дію універсальним законом драматичного та музичного театру, висловлюючи думку, що тільки дотримання його може надати постановці опери театральну дієвість [4, 102]. Правда, оперний режисер домагався дієвості протилежним методом, визнаючи музику початковим імпульсом, що спонукає співака-актора до дії, тобто від внутрішнього імпульсу до зовнішнього ефекту.

Узагальнивши досвід світового театру, П. Паві зосередив увагу на двох концепціях дії персонажа; згідно з екзистенціальною концепцією дія є первинною, за ії̈ допомогою визначаються характери, позиції, відносини дійових осіб; екзистенціальна концепція передбачає первинність психологічної підоснови характерів і вчинків за межами конкретних дій, які відбуваються внаслідок їх проявів. В оперному мистецтві спостерігається синтез двох протилежностей: особливо він очікується у творах, основу лібрето яких складають шедеври світової поезії та драми з глибоким психологічним опрацюванням характерів та їх адекватним відображенням в музичному матеріалі [2].

Висновки. Таким чином, при роботі вокаліста над створенням образу оперного персонажа слід враховувати, що дія трактується як сукупність реакцій людини на обставини, вона входить до складу вчинку і підпорядковується його спонукальним мотивам та прагне до досягнення мети. Але дії та рух заздалегідь зазвичай не плануються лише у повсякденній реальності; сценічне життя, навпаки, передбачає наявність у виконавця обдуманих реакцій - навмисно видимі рухи і дії, що здійснюються від імені персонажа з єдиною метою розкрити свідомі, несвідомі або приховані рухи думки, переживання героя. Отже лише у стані перевтілення співака в співака-актора, розпоряджаючись його психофізикою, сам персонаж виявляє дієву свободу.

Дієвий імпульс, в якій би формі він не був здійснений, передбачає подальшу трансформацію сценічної ситуації, взаємовідносин, поведінки персонажів, психологічних змін. Цей критерій допомагає виконавцю вибудувати лаконічну дієву лінію з згідно музичним матеріалом і, з одного боку, сприяти передачі рушійної сили дії персонажа, з іншого - відзначити, в які моменти задум композитора диктує перетворення цього динамічного елемента емоційного стану, і знайти спосіб його вираження. Як сказав В. Фельзенштейн, торкаючись методології музичного театру, співак-актор «розуміє, що він - і коли співає, і коли не співає - діє під час навіть своєю присутністю на сцені. Лише тепер він дізнається, що означає «дія»» $[4,102]$. Таким 
чином, у кожному інструментальному і вокальному ряді тонів має бути відображена драматична дія, а у динаміці музичного розвитку та темпових позначках слід перш за все бачити виразність, а не технічні позначення.

\section{СПИСОК ЛИТЕАРТУРЫ}

1. Горчаков Н. К. С. Станиславский о работе режиссера с актером. М. : BTO, 1958. 283 c.

2. Пави П. Словарь театра. М.: Прогресс, 1991. 504 с.

3. Самойленко А. Музыковедение и методология гуманитарного знания. Проблема диалога. Одесса : Астропринт, 2002. 244 с.

4. Фельзенштейн В. О музыкальном театре. М. : Радуга, 1984. 456 с.

5. Черкашина-Губаренко М. Р. Размышления о феномене оперы. Черкашина-Губаренко М. Р. Музика і театр на перехресті епох : збірник статей : у 2 т. Т. 1. Київ, 2002. С. 43-56.

\section{REFERENCES}

1. Gorchakov, N. (1958) K. S. Stanislavsky on the work of the director with the actor. M.: WTO. [in Russian]

2. Pavi, P. (1991) Dictionary of the theater. Moscow: Progress. [in Russian]

3. Samoylenko, A. (2002) Musicology and methodology of humanitarian knowledge. The problem of dialogue. Odessa: Astroprint, 2002. [in Russian]

4. Felsenstein, V. (1984) About the musical theater. M.: Rainbow, 1984. [in Russian]

5. Cherkashina-Gubarenko, M. (2002) Reflections on the Phenomenon of the Opera, Cherkashina-Gubarenko, M. Muzyka and the Theater for Perepest of Epochs: Zbirnik articles: 2 t. T. 1. Kiev, 2002. P. 43-56. [in Russian]

Стаття надійшла до редакції 15.03.2017

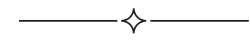

